\title{
Reevaluation of Chloropseudomonas ethylica Strain 2-K
}

\author{
B. H. GRAY, ${ }^{1}$ C. F. FOWLER ${ }^{2}$ N. A. NUGENT, N. RIGOPOULOS, and R. C. FULLER ${ }^{3}$ \\ The University of Tennessee-Oak Ridge Graduate School of Biomedical Sciences, and Biology Division, \\ Oak Ridge National Laboratory, Oak Ridge, Tennessee 37830
}

\begin{abstract}
Cultures of Chloropseudomonas ethylica strain $2-\mathrm{K}$ obtained from several laboratories were examined. All cultures examined to date in this laboratory contained nonmotile, green, photosynthetic bacteria (Chlorobiaceae) identical to published descriptions of Chlorobium limicola and at least one colorless, motile bacterium. All attempts to isolate motile photosynthetic bacteria corresponding to published descriptions of $C$. ethylica from such cultures have been unsuccessful. Several physiological characteristics previously ascribed to $C$. ethylica $2-\mathrm{K}$ are expressions of mixed cultures rather than the property of a single species.
\end{abstract}

Chloropseudomonas ethylica strain $2-\mathrm{K}$ was first described by Shaposhnikov et al. (18) as a motile, green, photosynthetic bacterium of the family Chlorobiaceae. A subculture of $C$. ethylica strain $2-\mathrm{K}$ obtained from Kondrat'eva was initially grown and observed in the United States at Brookhaven National Laboratory in 1961. Preliminary observations showed that the culture contained obvious photosynthetic and nonphotosynthetic contaminants in addition to green, photosynthetic bacteria (J. M. Olson, N. Rigopoulos, and R. C. Fuller, unpublished observations). The original mixture grew vigorously on modified Larsen's medium $(3,9)$. When the original mixed culture was used as an inoculum for shake cultures, two types of green, lenticular colonies grew, and one was considerably larger than the other after 3 weeks of incubation. Liquid cultures grown from each of these green colonies contained various morphological forms, which for many years were assumed to be pleomorphic forms of a single species. Because the cell pleomorphism and two sizes of green colonies were reproducible properties of cultures grown from inocula taken from large, green colonies, the cultures grown from the large, green colonies were

\footnotetext{
${ }^{1}$ Present address: Radiation Biology Laboratory, Smithsonian Institution, 12441 Parklawn Drive, Rockville, Md. 20852.

${ }^{2}$ Present address: Research Institute for Advanced Studies, 1450 South Rolling Road, Baltimore, Md. 21227.

${ }^{3}$ Present address: Department of Biochemistry, University of Massachusetts, Amherst, Mass. 01002.
}

assumed to be pure. In addition, many physiological characteristics of $C$. ethylica $2-\mathrm{K}$ originally described by Shaposhnikov et al. (18) matched those of the culture reisolated at Brookhaven. A stock culture prepared from large, green colonies at Brookhaven in 1961 was the original source of $C$. ethylica used in many laboratories for the past 10 years.

Cultures of $C$. ethylica recently obtained from several laboratories in Japan, England, and the United States were examined to determine whether the two sizes of green colonies, various morphological cell types, and anomalous biochemical characteristics were in fact manifestations of a single bacterial species or a result of mixed cultures of organisms. On the basis of the data presented in this report, it is proposed that the 1961 Brookhaven culture is a combination of (i) a photosynthetic, green, nonmotile autotroph that oxidizes sulfide and (ii) a nonphotosynthetic bacterium.

\section{MATERIALS AND METHODS}

Cultures and media. The $C$. ethylica cultures investigated were obtained from laboratories in the United States, Great Britain, and Japan. Although the strain of each $C$. ethylica culture was not definitively known, all but one culture could be traced back to the 1961 Brookhaven reisolate. C. ethylica was cultured on a medium of the following composition (medium A): $\mathrm{KH}_{2} \mathrm{PO}_{4}, 1.0 \mathrm{~g} ; \mathrm{NH}_{4} \mathrm{Cl}, 1.0 \mathrm{~g} ; \mathrm{MgCl}_{2} \cdot 6 \mathrm{H}_{2} \mathrm{O}, 5.0$ g; $\mathrm{NaCl}, 20.0 \mathrm{~g} ; \mathrm{CaCl}, 40 \mathrm{mg} ; \mathrm{NaHCO}_{3}, 4.0 \mathrm{~g}$; $\mathrm{Na}_{2} \mathrm{~S} \cdot 9 \mathrm{H}_{2} \mathrm{O}, 0.2 \mathrm{~g}$; sodium acetate, $2.0 \mathrm{~g}$; iron solution, $5.0 \mathrm{ml}$; Larsen's trace elements, $1.0 \mathrm{ml}$; and 
water to 1.0 liter $(3,9)$. The $\mathrm{pH}$ of the medium was 7.3 to 7.6 . Cultures were incubated at 28 to $30 \mathrm{C}$ and at 860.8 to 1,076 lux light intensity.

The green, photosynthetic rod isolated during these investigations was cultured on a medium identical to medium A with the following alterations (medium B): the $\mathrm{Na}_{2} \mathrm{~S} \cdot 9 \mathrm{H}_{2} \mathrm{O}$ concentration was increased 10 -fold, from 0.2 to $2.0 \mathrm{~g}$ in 1.0 liter, and sodium acetate was omitted. When additional carbon compounds were added to medium $\mathrm{B}$, they were added as solutions adjusted to $\mathrm{pH} 7$ to 8 and sterilized by filtration or autoclaving. Incubation conditions were identical to those used to grow C. ethylica.

The nonphotosynthetic heterotroph isolated during these investigations was cultured on a medium of the following composition (medium $\mathrm{C}$ ): $\mathrm{K}_{2} \mathrm{HPO}_{4}, 0.5 \mathrm{~g}$; $\mathrm{NH}_{4} \mathrm{Cl}, 1.0 \mathrm{~g} ; \mathrm{Na}_{2} \mathrm{SO}_{4}, 1.0 \mathrm{~g} ; \mathrm{CaCl}_{2} \cdot 6 \mathrm{H}_{2} \mathrm{O}, 0.1 \mathrm{~g}$; $\mathrm{MgSO}_{4} \cdot 7 \mathrm{H}_{2} \mathrm{O}, 2.0 \mathrm{~g} ; \mathrm{NaCl}, 20.0 \mathrm{~g}$; cysteine hydrochloride, $0.875 \mathrm{~g}$; yeast extract, $1.0 \mathrm{~g}$; peptone, $1.0 \mathrm{~g}$; malic acid, $2.0 \mathrm{~g}$; iron solution (3), $5.0 \mathrm{ml}$; Larsen's trace elements (9), $1.0 \mathrm{ml}$; and water to 1.0 liter. The medium was adjusted to $\mathrm{pH} 6.9$ to 7.1 with sodium hydroxide before it was autoclaved. Cultures were incubated at 28 to $30 \mathrm{C}$ at a light intensity of less than 1,076 lux or in the dark.

Shake cultures were prepared by modifying the procedures of van Niel (20) in the following ways: Ionagar (Colab Laboratories, Inc.) was used at a concentration of $0.85 \%$ to solidify liquid media; no paraffin plug was used to decrease diffusion of air into cultures. Shake cultures in medium A contained a final $\mathrm{Na}_{2} \mathrm{~S} \cdot 9 \mathrm{H}_{2} \mathrm{O}$ concentration of $0.05 \%$. Yeast extract (Difco) and peptone (Difco) when included were at final concentrations of $0.05 \%$. Screw-cap tubes with Teflon cap liners and containing either 20 or $30 \mathrm{ml}$ of an agar medium were prepared. The first tube of each series was inoculated with a culture sample. Serial dilutions then were made by consecutive $1.0-\mathrm{ml}$ transfers.

Staining and photography of cells and colonies. Gram staining was done by the method of Baker (1) on samples removed directly from cultures. Photomicrographs were made with the aid of a Zeiss Ultraphot II microscope. Electron micrographs were made of a harvested culture suspended in $\mathrm{L}$ broth (Difco) at heavy cell concentrations. Samples were placed on grids, stained with phosphotungstic acid, and photographed through a Siemens $1 \mathrm{~A}$ electron microscope. The agar shakes photographed were 3 weeks old. Tubes were broken, and the agar was removed and sliced into thin sections before being photographed.

Spectrophotometry. A Cary model 14 recording spectrophotometer equipped with an RCA C31025C extended-range photomultiplier tube was used to measure absorption spectra. Liquid cultures were harvested by centrifugation at $10,000 \times g$ for $15 \mathrm{~min}$ at 0 to $5 \mathrm{C}$. Whole cells were washed once in freshly prepared $0.01 \mathrm{M}$ potassium phosphate ( $\mathrm{pH}$.7.5) containing $0.01 \mathrm{M}$ sodium ascorbate $(\mathrm{pH} 7.5)$. In vivo spectra were made by using opal glass. Optical densities of growing cultures were determined at 600 nm. Elemental sulfur formed during growth was removed by centrifugation for $2 \mathrm{~min}$ at $1,000 \times g$ prior to such measurements.

\section{RESULTS}

Figure 1 shows the large and small green colonies found in shake cultures of $C$. ethylica grown in medium $A$. Those colonies that developed into large green colonies were visible in 40 to $72 \mathrm{~h}$ at a magnification of $30 \times$ under a dissecting microscope, whereas small green colonies appeared only after 5 to 7 days of incubation. Upon addition of yeast extract to the shake cultures prepared in medium A, colorless colonies also appeared throughout the tube after 2 to 3 days of incubation. These colonies were not visible in shake cultures lacking yeast extract. They were especially numerous in the regions immediately above the level at which photosynthetic growth was inhibited. Growth of the colorless colonies was much more rapid than was growth of the small green colonies under these conditions. Isolated, large green colonies placed in liquid medium $\mathbf{A}$ $\left(0.02 \% \mathrm{Na}_{2} \mathrm{~S} \cdot 9 \mathrm{H}_{2} \mathrm{O}\right)$ grew readily. Figure $2 \mathrm{a}$ shows an electron micrograph of cells obtained from such a culture. Every liquid culture grown from large green colonies that was examined by electron microscopy contained both flagellated and nonflagellated cells. Light microscopy observations confirmed the presence of both nonmotile and motile cells in such cultures. In addition, the motility in liquid cultures grown from large green colonies was of the leisurely type expected from a cell having a single eccentric flagellum. The nonflagellated forms appeared similar to those cells photographed in 1966, which demonstrated the presence of chlorobium vesicles in $C$. ethylica $2-\mathrm{K}$ (7). Shake cultures made either from large green colonies or from liquid cultures grown from large green colonies gave results identical to those described above; i.e., colorless colonies were present in yeast-supplemented shakes, and large and small green colonies were present in regular and yeast-supplemented shakes.

However, when small green colonies were picked from a high-dilution shake tube (medium A) lacking large green or colorless colonies and a second series of shake cultures was prepared directly from such a colony, the results were completely different. Figure 3 is a photograph of a section of one such shake culture column. Large green colonies and colorless colonies were absent; only small green colonies of uniform size appeared in the agar shake culture with or without yeast extract supplement. Isolation of a small green colony from a second series of shake cultures and repetition of this procedure in a third series of shake cultures also yielded small green colonies of uniform size. When isolated, small green 


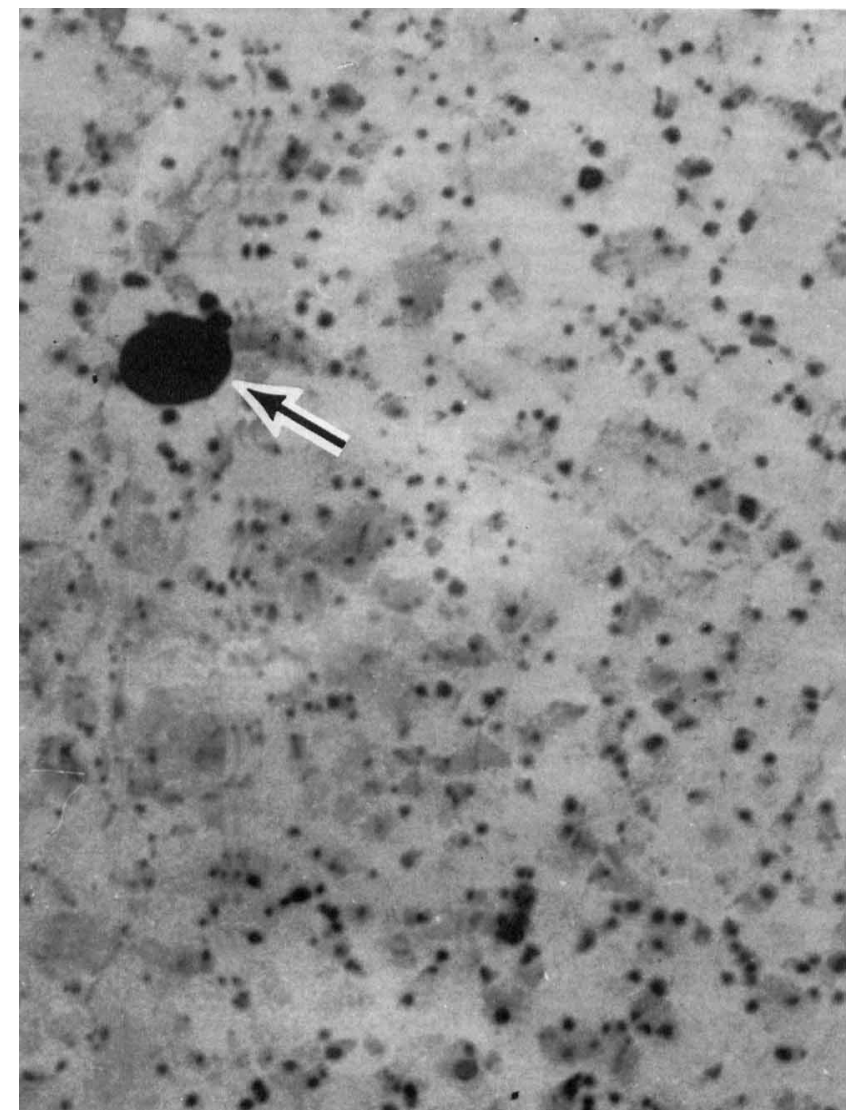

FIG. 1. Photograph of a section from a shake culture of C. ethylica (see Materials and Methods section). The sample is from a tube containing a $2.7 \times 10^{4}$-fold dilution of a liquid culture. The large green colony, indicated by the arrow, is about $1.0 \mathrm{~mm}$ in diameter.

colonies were used as the inoculum for liquid medium A $\left(0.02 \% \mathrm{Na}_{2} \mathrm{~S} \cdot 9 \mathrm{H}_{2} \mathrm{O}\right)$, very marginal, if any, growth occurred. Enrichment of medium A with yeast extract, peptone, or Ionagar at final concentrations of $0.05 \%$ singly or in combination did not cause increased growth. However, when the sodium sulfide concentration was increased to $0.2 \%$ (medium B), growth was obtained.

Photomicrographs of cells from liquid cultures of the isolated green bacteria (medium B) and the mixed culture (medium A) are shown in Fig. 4. The presence of short rods and chains of rods is striking in the pure culture (small green colony, Fig. 4a). Fig. 4 b shows a similar photograph of the mixed culture (large green colony), illustrating the presence of two morphological cell types. All cells were gram negative. Figure $2 \mathrm{~b}$ shows an electron micrograph of cells from liquid cultures (medium B) grown from small green colonies that demonstrate a lack of flagella readily observed in the mixed cultures (Fig. 2a). Although numerous fields were photographed and many additional fields were scanned, no flagellated cells were ever observed in pure cultures of the isolated green bacteria. In addition, no motility was ever observed in pure cultures of the isolated green bacteria.

Optimal autotrophic growth conditions for the isolated green organism in liquid cultures were $2 \% \mathrm{NaCl}, \mathrm{pH} 7.2$ to 7.5 , and $0.2 \%$ $\mathrm{Na}_{2} \mathrm{~S} \cdot 9 \mathrm{H}_{2} \mathrm{O}$. Thiosulfate did not support growth. Only acetate enhanced growth in the presence of $\mathrm{CO}_{2}$ as the only other carbon source. Ethanol or a series of organic acids and sugars did not enhance growth in the presence of $\mathrm{CO}_{2}$. These data agree with the acetate enhancement data found in Chlorobium thiosulfatophilum (17). No growth occurred in liquid cultures lacking $\mathrm{CO}_{2}$ or in any culture incubated in the dark. Contrary to the findings of Kondrat'eva et al. (8) with $C$. ethylica, growth of pure cultures of the isolated green 
bacteria was not stimulated by supplementing the medium with various organic compounds. The isolated green bacterium had absorption maxima at 458 and $750 \mathrm{~nm}$ (Fig. 5). The $80 \%$ methanol extract had absorption maxima at 435 and $670 \mathrm{~nm}$. These spectra are similar to
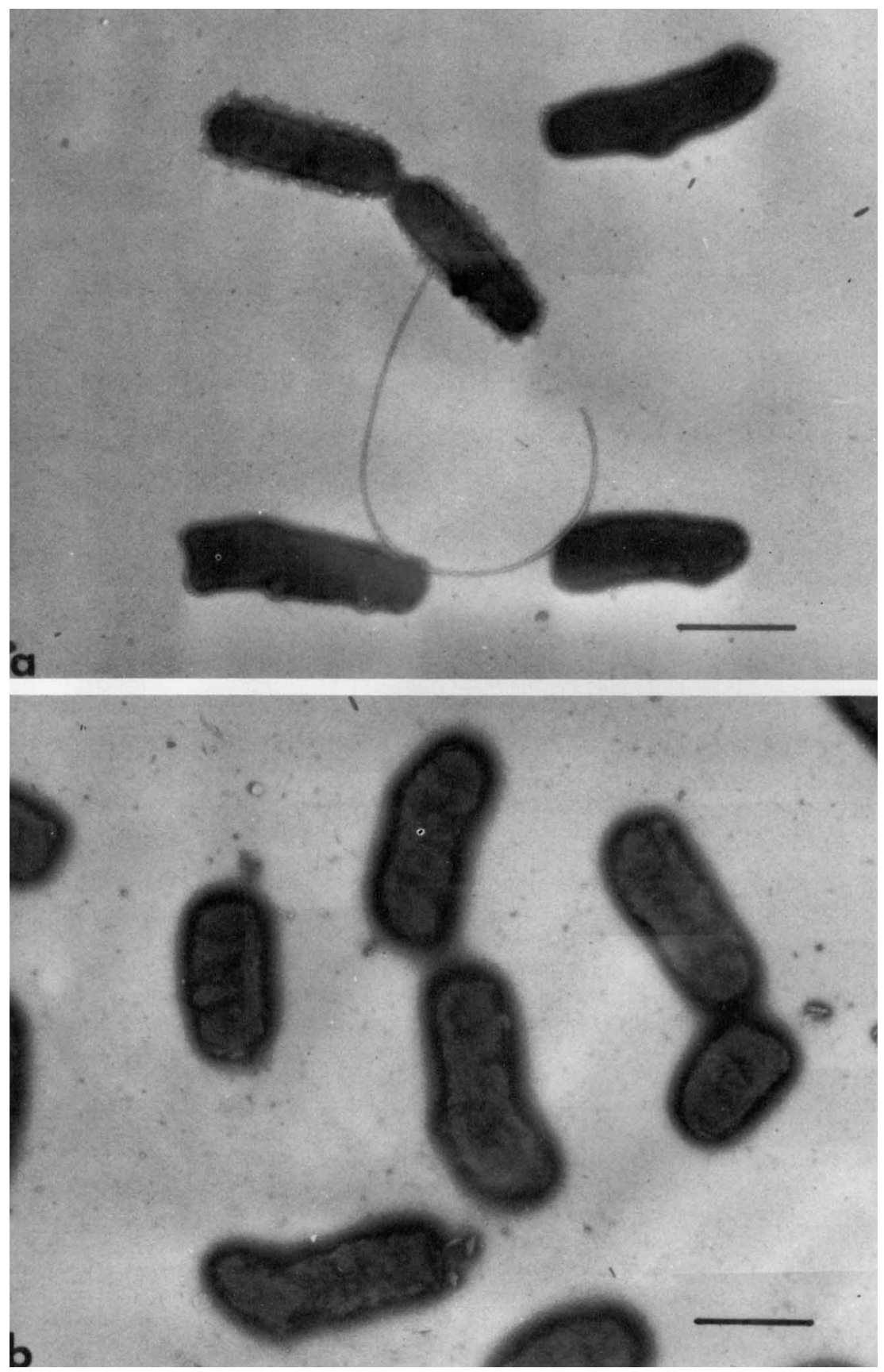

FIG. 2. (a) Electron micrograph of cells from a liquid culture grown from a large, green colony inoculum. The flagellated form appears to have a single nonpolar flagellum. The culture was about $40 \mathrm{~h}$ old when harvested. The bar represents $1.5 \mu \mathrm{m}$. (b) Electron micrograph of cells from a liquid culture about $40 \mathrm{~h}$ old grown from a small green colony inoculum. The bar represents $1.5 \mu \mathrm{m}$. 


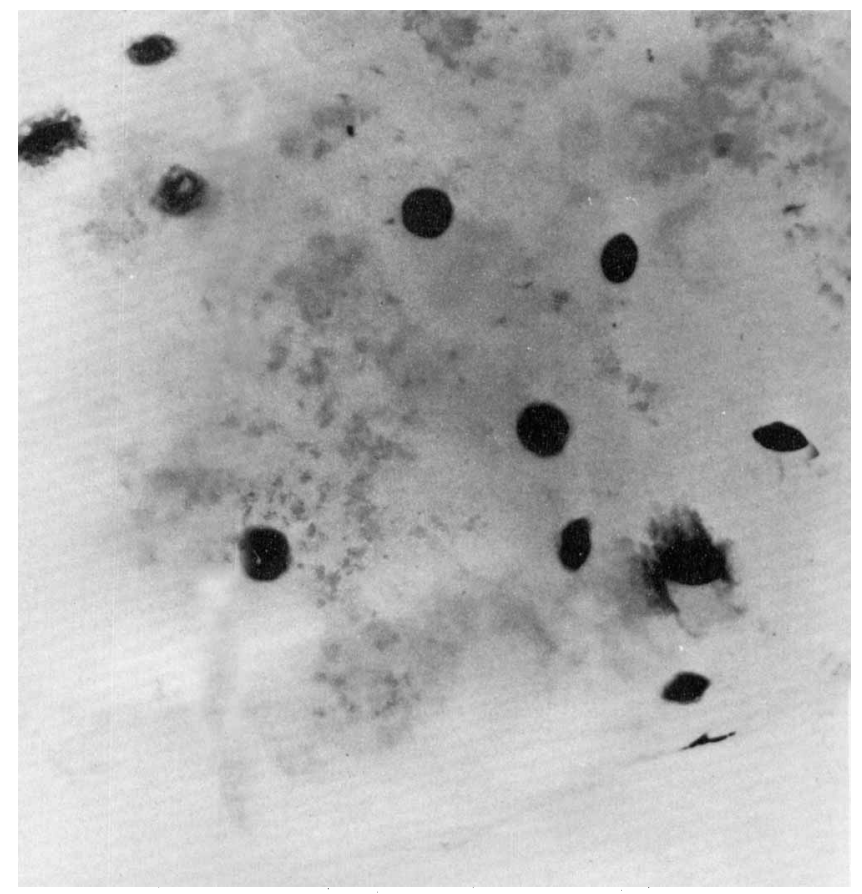

FIG. 3. Photograph of a section from a shake culture (see Materials and Methods) of the isolated green bacterium in a yeast-supplemented agar medium. All colonies are green, lenticular, and smooth. They lack the diffuseness typical of motile organisms. Deposits around the colony may be sulfur or iron sulfides. The field shown is from an $8.1 \times 10^{5}$-fold dilution of the culture. Colonies are about $0.2 \mathrm{~mm}$ in diameter.

spectra of Chlorobium species (5).

It has been possible to isolate an as yet unidentified heterotroph from $C$. ethylica cultures by selective enrichment, followed by single-colony isolation by the shake culture technique. $C$. ethylica cultures were incubated in the light at 28 to $30 \mathrm{C}$ in medium $\mathrm{A}$ supplemented with yeast extract and peptone. Shake cultures were prepared in medium $\mathrm{C}$ by inoculation with $1-\mathrm{ml}$ portions from the enrichment cultures. These shake cultures were incubated in the dark. Isolated colonies from high-dilution shake cultures were used as the inoculum for a second series of shake cultures (medium $\mathrm{C}$ ), and the procedure was repeated in a third series. All the colonies in the second and third series of shake cultures were light brown, lenticular, and uniformly sized. Stock stab cultures of the organism were prepared by inoculation of solid ( $0.85 \%$ Ionagar) medium $\mathrm{C}$ with cells from isolated colonies obtained from high-dilution shake culture tubes from the third series. Cells from liquid cultures grown in medium C (Fig. 6) appeared to have a single eccentrically located flagellum. They show weak motility and could be defined as degenerately peritrichous (19).

When $0.5-\mathrm{ml}$ samples from cultures of the isolated, green, photosynthetic bacteria and the weakly motile nonphotosynthetic heterotroph were mixed together in $30 \mathrm{ml}$ of liquid medium A $\left(0.02 \% \quad \mathrm{Na}_{2} \mathrm{~S} \cdot 9 \mathrm{H}_{2} \mathrm{O}\right)$, vigorous deep-green growth occurred in the light at 28 to $30 \mathrm{C}$. Neither the isolated green photosynthetic bacteria nor the isolated heterotroph grew alone in medium A under any growth conditions tested. Moreover, large and small green colonies grew in shake cultures (medium A) when the deep-green mixed culture was the inoculum. Shake cultures (medium A) supplemented with yeast extract contained large and small green colonies plus colorless colonies. Therefore, by mixing the two organisms (the green, nonmotile phototroph and the motile heterotroph), one can "recreate" C. ethylica.

It was possible to observe what appeared to be vibrios in several alleged cultures of $C$. ethylica. Shake cultures prepared from $C$. ethylica cultures obtained from one laboratory contained colorless colonies that were diffuse. However, no attempt to isolate in pure culture other heterotrophic organisms from C. ethylica cultures has been made.

Finally, attempts were made with every alleged $C$. ethylica culture examined to select motile photosynthetic organisms by allowing migration in a light gradient (21). Medium B containing $0.2 \%$ Ionagar was inoculated, and 

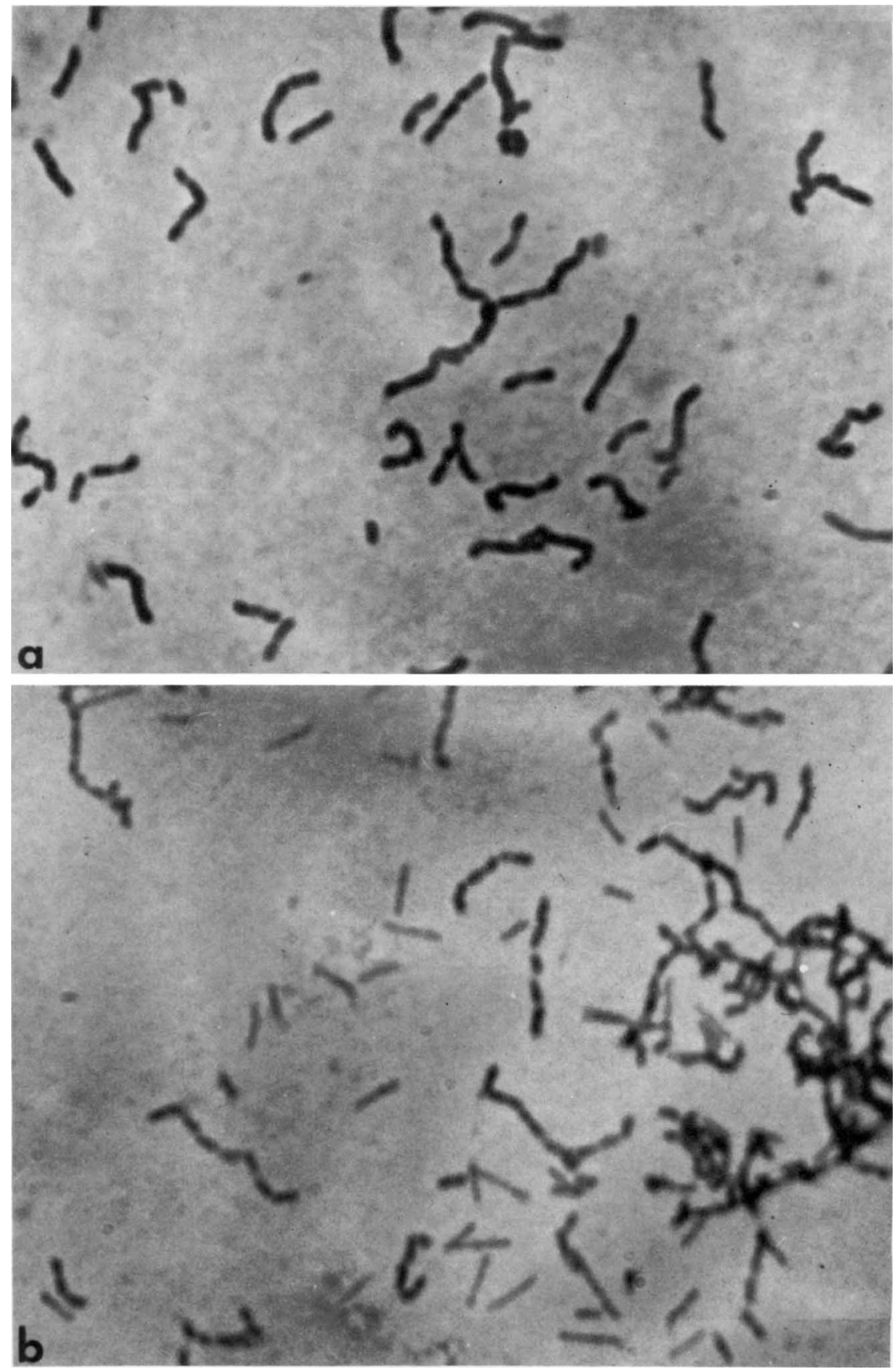

FIG. 4. (a) Photograph of gram-stained cells of the pure green organism (from small green colonies). (b) Similar photograph of the mixed culture (from large green colonies). $\times 2500$.

organisms were allowed to migrate towards a region with 860.8 to 1,076 lux incident light intensity. Although the cultures were maintained in the light gradient for as long as 2 months, no motile photosynthetic organism could be observed or recovered.

\section{DISCUSSION}

The data reported above on colony types and cell morphology lead to the conclusion that the cultures presumed to be $C$. ethylica strain $2-\mathrm{K}$ which were investigated are instead mixtures of 


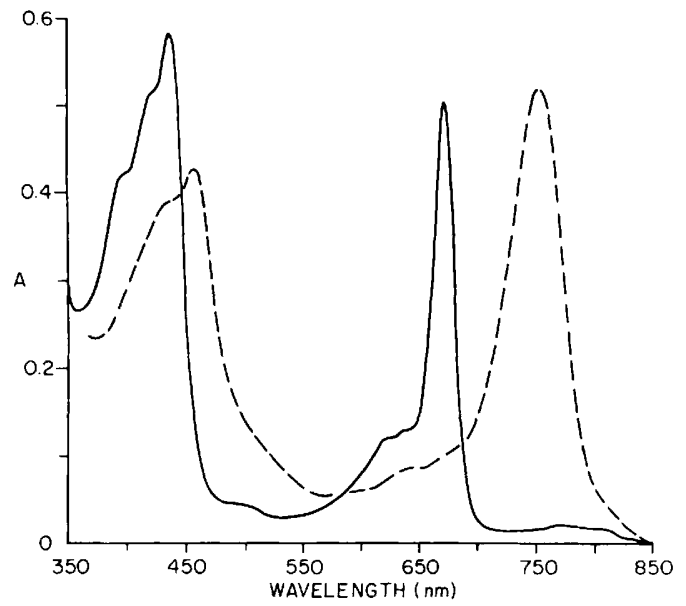

FIG. 5. In vivo absorption spectrum of the isolated green bacteria grown from a small green colony inoculum (---). The absorption maxima are at 458 and $750 \mathrm{~nm}$. Opal glass was used to make the spectrum. Also shown is the absorption spectrum of an $80 \%$ methanol extract of the isolated green bacteria (--). Maxima are at 435 and $670 \mathrm{~nm}$.

a nonmotile, green photosynthetic bacterium and one or more species of motile colorless bacteria. A syntrophic relationship similar to those described in the cases of Desulfovibrio desulfuricans (15) and Methanobacillus omelianskii (4) apparently exists in these cultures grown on medium $A$. The isolated green rod has all the characteristics of a marine Chlorobium limicola; i.e., it is a gram-negative, nonmotile, photoautotrophic, short rod that contains Chlorobium chlorophyll and will not grow with thiosulfate as a reductant $(5,9,11$, 20). The isolated, small green colonies in agar shake cultures are apparently $C$. limicola. Large green colonies are probably a combination of $C$. limicola and one or more species of rapidly growing colorless organisms. Nutrients present in yeast extract permit independent colony growth of the colorless microbes in agar shake cultures. Analysis of every C. ethylica cultures obtained shows the same basic profile. Attempts to isolate or observe green motile rods from such cultures have been unsuccessful. Moreover, since the time of reisolation of the presumed pleomorphic bacterium at Brookhaven in 1961, large and small green colonies have been present in every series of shake cultures of $C$. ethylica prepared in this laboratory from the original culture and its descendants and from cultures obtained by us from other laboratories in the United States, Japan, and England.

The weakly motile heterotroph and $C$. limicola, both isolated from mixed cultures misnamed $C$. ethylica, when placed in medium A $\left(0.02 \% \quad \mathrm{Na}_{2} \mathrm{~S} \cdot 9 \mathrm{H}_{2} \mathrm{O}\right)$ produced vigorously growing green cultures with many of the characteristics ascribed to $C$. ethylica. Because heavy green growth occurred in mixed cultures containing $0.02 \% \mathrm{Na}_{2} \mathrm{~S} \cdot 9 \mathrm{H}_{2} \mathrm{O}$ and meager or no growth occurred in cultures of isolated $C$. limicola at the same sulfide concentration, it is reasonable to assume that the heterotroph isolated can produce sulfide. Moreover, $c$ cytochromes with low midpoint redox potential, characteristic of many sulfate-reducing bacteria (16), have been reported to be present in $C$. ethylica $(2,10,12)$. We have previously shown that cytochrome 551.5 present in cultures misnamed $C$. ethylica was lacking in pure cultures of the isolated green bacterium $C$. limicola (6). These data suggest that the heterotroph isolated during these investigations may be able to reduce oxidized forms of sulfu:

It is important to note that photosynthetic sulfur bacteria and sulfate-reducing bacteria are often found in the same habitats (13). Sulfur oxidation and reduction occur in such mixtures as well as in cultures maintained in the laboratory (14). Indeed, chloride or other anions are often substituted for sulfates in media designed for enrichment of nonsulfur photosynthetic bacteria, in the hope that sulfate-reducing bacteria will be selected against (20). Ironically, oxidized forms of sulfur are metabolic products of green photosynthetic bacteria and thus cannot be excluded from such enrichments for these microbes.

It cannot be proved that the original culture obtained at Brookhaven lacked a motile chloropseudomonad. It is quite possible that the shake cultures prepared at Brookhaven in 1961 contained an organism properly described as $C$. ethylica. Unfortunately, colorless motile bacteria in combination with $C$. limicola were probably selected as the "organism" from the shake cultures that most clearly resembled the original description of Chloropseudomonas. On the other hand, it is possible that the original culture obtained by Olson from Kondrat'eva did not contain a green photosynthetic pseudomonad. If this were true, $C$. ethylica would be an invalid species. This conclusion is substantiated by and our results are in agreement with the findings of $N$. Pfennig and $E$. Siefert, who examined strains $\mathrm{N}_{2}$ and $\mathrm{N}_{3}$ of $C$. ethylica obtained by M. C. W. Evans in late 1968 from the laboratory of Kondrat'eva. Neither Pfennig nor Siefert was able to isolate a motile green sulfur bacterium with the characteristic properties of $C$. ethylica from these two strains (N. Pfennig and M. C. W. Evans, personal communication). 


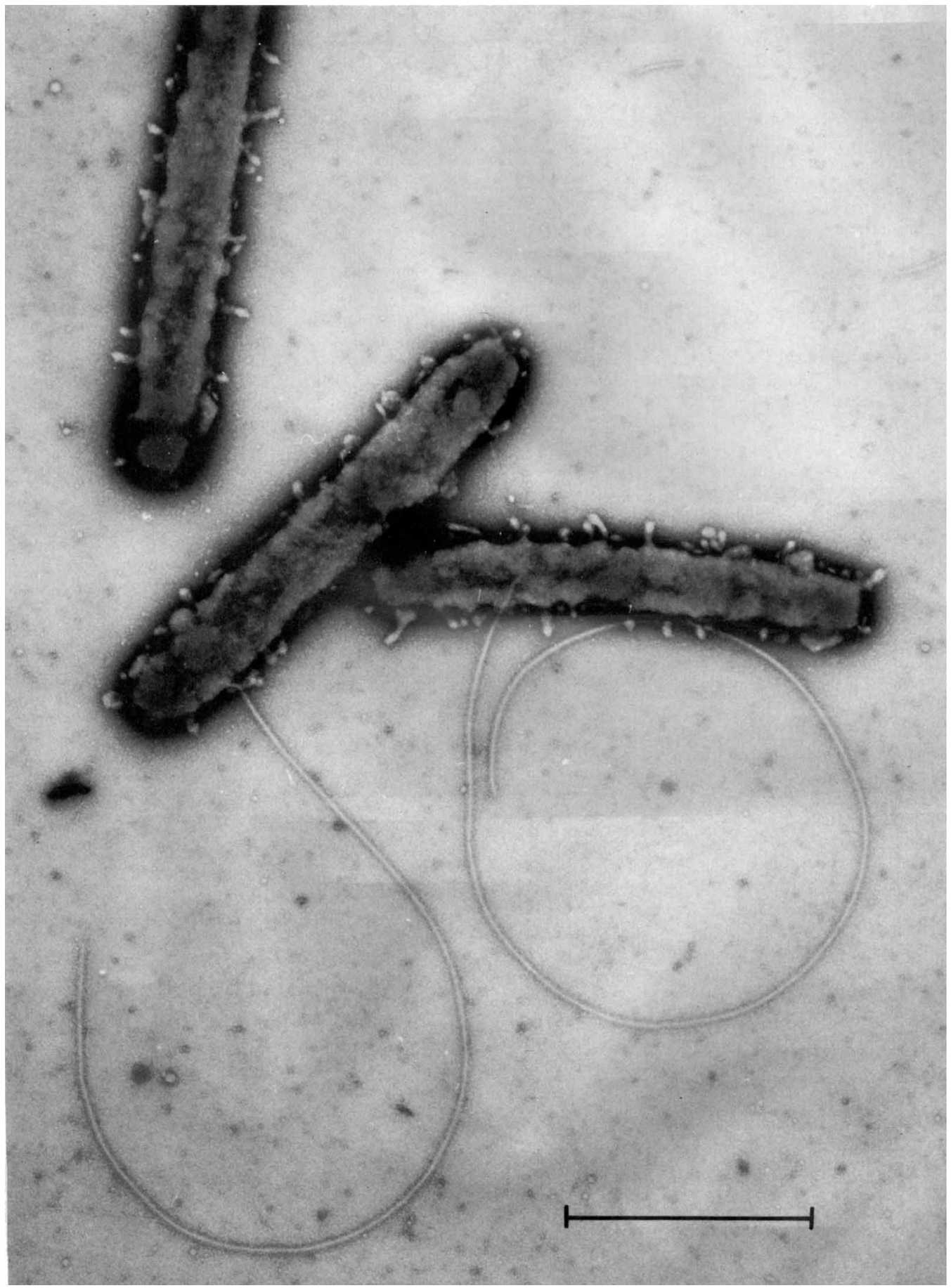

FIG. 6. Electronmicrograph of cells from a liquid culture of the heterotroph. The bar represents $1.0 \mu \mathrm{m}$.

\section{ACKNOWLEDGMENTS}

We gratefully acknowledge the assistance of D. E. Foard in obtaining the photomicrographs. The elec- tron micrographs of numerous cultures were taken by D. P. Allison, and the photographs of agar cultures were taken by W. N. Shipley. Also, several helpful suggestions have been made by S. F. Carson, I. R. 
Joint, and Mr. E. F. Phares. Their pertinent comments were greatly appreciated.

This research was sponsored by the U.S. Atomic Energy Commission under contract with the Union Carbide Corporation. B.H.G., a University of Tennessee predoctoral trainee, was supported by grant GM 1974 from the National Institute of General Medical Sciences. C. F. F. was supported by postdoctoral fellowship GM 39166 from the National Institute of General Medical Sciences.

This study is a part of a thesis submitted by B. H. Gray to the University of Tennessee in partial fulfillment of the requirements for a Ph.D. degree.

\section{REPRINT REQUESTS}

Address requests for reprints to: R. C. Fuller, Department of Biochemistry, University of Massachusetts, Amherst, Mass. 01002.

\section{LITERATURE CITED}

1. Baker, F. J. 1967. Handbook of bacteriological techniques, p. 20-30. Butterworth, London.

2. Bartsch, R. G. 1971. Cytochromes: bacterial, p. 344-363. In A. San Pietro, (ed.), Methods in enzymology, vol. 23. Academic Press Inc., New York.

3. Bose, S. K. 1963. Media for anaerobic growth of photosynthetic bacteria, p. 510. In H. Gest, A. San Pietro, and I. P. Vernon, (ed.), Bacterial photosynthesis. The Antioch Press, Yellow Springs, Ohio.

4. Bryant, M. P., E. A. Wolin, M. J. Wolin, and R. S. Wolfe. 1967. Methanobacillus omelianskii, a symbiotic association of two species of bacteria. Arch. Mikrobiol. 59:20-31.

5. Clayton, R. K. 1963. Absorption spectra of photosynthetic bacteria and their chlorophylls, p. 495-500. In H. Gest, A. San Pietro, and L. P. Vernon, (ed.), Bacterial photosynthesis. The Antioch Press, Yellow Springs, Ohio.

6. Gray, B. H., C. F. Fowler, N. A. Nugent, and R. C. Fuller. 1972. The absence of the low potential cytochrome 551.5 in green bacteria isolated from Chloropseudomonas ethylica. Biochem. Biophys. Res Commun. 47:322-327.

7. Holt, S. C., S. F. Conti, and R. C. Fuller. 1966. Photosynthetic apparatus in the green bacterium Chloropseudomonas ethylicum. J. Bacteriol. 91:311-323.
8. Kondrat'eva, E. N., L. N. Petrova, and E. P. Fedenko. 1968. Use of organic compounds by the green bacterium Chloropseudomonas ethylicum in relation to the presence of carbon dioxide and hydrogen sulfide. Dokl. Akad. Nauk SSSR (translation) 154:385-389.

9. Larsen, H. 1952. On the culture and general physiology of the green sulfur bacteria. J. Bacteriol. 64:187-196.

10. Meyer, T. E., R. G. Bartsch, and M. D. Kamen. 1971. Cytochrome $C_{3}$. A class of electron transfer heme proteins found in both photosynthetic and sulfate-reducing bacteria. Biochim. Biophys. Acta 245:453-464.

11. Nadson, G. 1906. Chlorobium limicola Nads., green chlorophyll-bearing microbe. Bull. Jard. Bot. St. Petersburg (translation) 6:190-194.

12. Olson, J. M., and E. K. Shaw. 1969. Cytochromes from the green photosynthetic bacterium Chloropseudomonas ethylicum. Photosynthetica 3:288-290.

13. Pfennig, N. 1967. Photosynthetic bacteria. Annu. Rev. Microbiol. 21:285-324.

14. Pfennig, N., and G. Cohen-Bazire. 1967. Some properties of the green bacterium Pelodictyon clathratiforme. Arch. Mikrobiol. 59:226-236.

15. Postgate, J. R. 1953. On the nutrition of Desulphovibrio desulphuricans: a correction. J. Gen. Microbiol. 9:440-444.

16. Postgate, J. R. 1966. Cytochrome $\mathrm{C}_{3}$ and desulphoviridin: pigments of the anaerobe Desulphovibrio desulphuricans. J. Gen. Microbiol. 14:545.

17. Sadler, W. R., and R. Y. Stanier. 1960. The function of acetate in photosynthesis of green bacteria. Proc. Nat. Acad. Sci. U.S.A. 46:1328-1334.

18. Shaposhnikov, V. V., E. N. Kondrat'eva, and V. D. Fedorov. 1960. A new species of green sulphur bacteria. Nature (London) 187:167-168.

19. Stanier, R. Y., M. Doudoroff, and E. A. Adelberg. 1971. General microbiology, p. 151. Macmillan and Co., Ltd., London.

20. van Niel, C. B. 1932. On the morphology and physiology of the purple and green sulphur bacteria. Arch. Mikrobiol. 3:1-112.

21. van Niel, C. B. 1971. Techniques for the enrichment, isolation, and maintenance of the photosynthetic bacteria, p. 1-28. In A. San Pietro (ed.), Methods in enzymology, vol. 23. Academic Press Inc., New York. 